\title{
Wilkierz dla przedmieść Torunia z 1637 roku
}

\author{
Mateusz Superczyński \\ Archiwum Państwowe w Toruniu
}

Wilkierze wydawane dla mieszkańców miast ziemi chełmińskiej znane są nam już od początku XIV stulecia ${ }^{1}$. Najstarsze takie dokumenty wystawiano dla najwcześniej lokowanych ośrodków miejskich, a więc dla Chełmna i Torunia ${ }^{2}$. W początkowym okresie ich istnienia ustrój regulowany był przywilejem chełmińskim z $1232 \mathrm{r}$. i jego odnowioną wersją z $1251 \mathrm{r}$. Pod koniec XIII w. dynamiczny rozwój miast spowodował konieczność uchwalania nowych aktów prawnych określających zasady życia gospodarczego, społecznego i ustrojowego. W tym okresie wystawcą takich dokumentów, nazywanych wilkierzami, były zazwyczaj władze zakonne $\mathrm{z}$ wielkim mistrzem na czele. Jednak w miare postępującej emancypacji stanów pruskich, a więc także mieszczaństwa, wilkierze i inne regulacje prawne zaczęły wystawiać rady miejskie, co było także przejawem wzrostu działalności legislacyjnej samorządu miejskiego.

\footnotetext{
${ }^{1}$ Warto wymienić choćby najstarszy wilkierz toruński, wydany dla Nowego Miasta Torunia, a datowany na około 1300 r.: Archiwum Państwowe w Toruniu, Akta miasta Torunia (dalej cyt. APT, AmT), Księgi i akta, Kat. II, sygn. I-1, s. 1-7, 18, 19, $23,25$.

${ }^{2}$ Edycję wilkierza dla miasta Chełmna i jego przedmieść z około 1400 r. opracował Arthur Semrau, uwzględniając także trzy inne wilkierze włączone do księgi czynszowej miasta Chełmna z około 1431 r.: A. Semrau, Die Willkür der Stadt Kulm von etwa 1400, Mitteilungen des Coppernicus Vereins fur Wissenschaft und Kunst zu Thorn, H. 37, Thorn 1927, s. 29-58.
} 
Celem wydawanych wilkierzy było uregulowanie wszelkich dziedzin życia społecznego, gospodarczego i obyczajowego na określonym obszarze bądź w pewnej grupie społecznej, dlatego można je podzielić według odbiorców na miejskie, cechowo-korporacyjne i wiejskie. Początkowo dokumenty te, w postaci pojedynczych rozporządzeń i artykułów, były spisywane na osobnych tabliczkach woskowych lub kartach papieru, które następnie przepisywano do ksiąg wilkierzy ${ }^{3}$. Przykładem kopiarza przywilejów i wilkierzy może być rękopis chełmiński założony przez pisarza miejskiego Konrada Bitschina w 1431 r. ${ }^{4}$ Przed wpisaniem do księgi wilkierz musiał być odczytany lub umieszczony w miejscu publicznym w celu zapoznania $\mathrm{z}$ jego treścią jak największej liczby mieszkańców. Zazwyczaj był to ratusz, a więc centralne miejsce w życiu każdego miasta. Od roku 1394, kiedy władze krzyżackie nakazały publiczne obwieszczanie nowo uchwalonych aktów prawnych w miastach, wilkierze były odczytywane lub wywieszane corocznie w święto Trzech Króli lub w Wielkim Poście 5 .

W zachowanych wilkierzach można wyróżnić kilka stałych elementów układu treści, na który składają się: wstęp, zbiór przepisów prawnych ujętych $\mathrm{w}$ oddzielne punkty i część końcowa. Wstęp wilkierza zawierał formułę konfirmacyjną, nagłówek określający treści uchwały, wystawcę, datę i sposób opublikowania. Na treść właściwą składały się poszczególne artykuły lub punkty, często z wyróżnionymi tytułami. Do rzadziej występujących elementów wilkierza należało zakończenie będące oddzielnym artykułem lub specjalnym sformułowaniem zawierającym na przykład sankcje za nieprzestrzeganie uchwały ${ }^{6}$.

Wszystkie ogólne wilkierze miejskie w Toruniu poruszały kilka zasadniczych dziedzin życia społecznego i gospodarczego. Do najważniejszych należały artykuły określające bądź regulujące kwestie zwią-

\footnotetext{
${ }^{3}$ T. Maciejewski, Wilkierze miasta Torunia, Poznań 1997, s. 26.

${ }^{4}$ Geheimes Staatsarchiv Preußisches Kulturbesitz (dalej cyt. GStAPK), XX Hauptabteilung (dalej cyt. HA), Ordensfolianten (dalej cyt. OF) sygn. 83; J. Tandecki, Średniowieczne księgi wielkich miast pruskich jako źródła historyczne i zabytki kultury mieszczańskiej (organizacja władz, zachowane archiwalia, działalność kancelarii), Warszawa-Toruń 1990, s. 90.

${ }^{5}$ T. Maciejewski, op. cit., s. 29-30.

${ }^{6}$ Ibid., s. 28-29.
} 
zane z ustrojem ośrodka miejskiego, które zazwyczaj umieszczano na początku aktu. W przypadku najstarszych wilkierzy, jak choćby Nowego Miasta Torunia z 1300 r., ustrój samorządu miejskiego określano na podstawie wcześniejszych przywilejów, jednak już akt z roku 1523, zwany Reformatio Sigismundi, zmieniał radykalnie organizację władz i ustrój miasta pod wpływem reform społecznych, powołując m.in. III ordynek jako organ reprezentacyjny pospólstwa miejskiego ${ }^{7}$. Niektóre wilkierze miejskie zawierały punkty określające bądź reformujące sądownictwo, a więc funkcjonowanie ław sądowych, sądów rady i burgrabiowskich. Aż do końca XVIII w. ustrój i sądownictwo regulowane w kolejno wydawanych wilkierzach oparte były na prawie chełmińskim $^{8}$.

W tekstach wilkierzy miejskich odrębne miejsce zajmowały przepisy związane z prawem karnym, jak i cywilnym. Pierwsze opisywały przestępstwa i kary, które stosowano wobec ich sprawców. W przypadku prawa cywilnego artykuły regulowały kwestie związane z przewłaszczaniem nieruchomości, testamentami, spadkami, własnością itd. Osobne punkty poświęcano sprawom związanym z handlem i rzemiosłem, choć w przypadku cechów częściej miały one swoje odrębne statuty, regulujące funkcjonowanie korporacji rzemieślniczych, natomiast punkty w wilkierzach miejskich jedynie częściowo dotykały spraw rzemieślniczych ${ }^{9}$. Dokumenty te zawierały przepisy o charakterze gospodar-

\footnotetext{
${ }^{7}$ APT, AmT, Kat. I, sygn. 2943.

${ }^{8}$ Prawo starochetmińskie 1584 (1394), pod red. W. Maisla i Z. Zdrójkowskiego, przekł. A. Bzdęga i A. Gaca, Torun 1985.

${ }^{9} \mathrm{Z}$ okresu średniowiecza liczne artykuły i statuty cechów wpisywano do ksiąg przywilejów, jak choćby do kopiarza przywilejów i wilkierzy K. Bitschina (J. Tandecki, op. cit., s. 92) bądź do księgi sądowej miasta Chełmna z lat 1330-1430: Das Kulmer Gerichtsbuch 1330-1430. Liber memoriarum Colmensis civitatis, bearb. von C. A Lückerath und F. Benninghoven, Köln 1999, nr 184, 221, 229, 246, 250, 272, 273, 293. Większość statutów zachowała się w ramach akt poszczególnych korporacji rzemieślniczych, a część z nich ukazała się drukiem: K. Ciesielska, Statut toruńskiego cechu murarzy z 1593 roku, Zapiski Historyczne, t. 27: 1962, z. 2, s. 213-228; B. Dybaś, Statut toruńskiego bractwa czeladzi murarskiej z 1617 r., Rocznik Toruński (dalej cyt. Rocz. Tor.), 1988, t. 18, s. 193-208; M. Magdański, Statut Toruńskiego Bractwa Czeladzi Ciesielskiej z 21 grudnia 1613 roku, Roczniki Historyczne, t. 13: 1937, s. 5261; Statut toruńskiego rzemiosła artystycznego i budowlanego z XVI-XVIII w., wyd.
} 
czym, administracyjnym i porządkowym. Poruszały kwestie związane z budownictwem, utrzymywaniem porządku na ulicach i posesjach, choć i w tym przypadku odnaleźć możemy osobne akty prawne odnoszące się do czystości w mieście ${ }^{10}$.

Do wilkierzy miejskich możemy zaliczyć grupę uchwał wydawanych specjalnie dla przedmieść i ich mieszkańców. Najstarszym zachowanym wilkierzem przedmiejskim jest niedatowany akt wydany dla przedmieść Chełmna, wpisany do księgi czynszowej z lat około $1403-1415^{11}$. Jest to dość rzadko spotykany rodzaj dokumentu, gdyż podobny z okresu średniowiecza, odnoszący się wyłącznie do przedmieść, nie zachował się. Dla toruńskich przedmieść osobny wilkierz wydano w roku 1637 i stanowił on najważniejszą regulację dla ludności zamieszkującej tereny poza murami miejskimi do końca XVIII w. Co prawda już w roku 1527 wydano tzw. Artykuły Mokrzańskie dla osady podmiejskiej Mokre, jednakże $\mathrm{z}$ racji pewnej odrębności ustrojowej i urbanistycznej nie uznajemy jej za przedmieście w rozumieniu tkanki osadniczej przylegającej do murów miasta ${ }^{12}$.

Wilkierz przedmiejski Torunia z 1637 r. stanowi pewne rozszerzenie wcześniejszych regulacji miejskich, szczególnie w zakresie ustanowienia urzędu kwaternego dla przedmieść i ich podziału na kwartały. Fakt uporządkowania spraw administracyjnych przedmieść wiązał się zapewne z budową nowych umocnień bastionowych od roku 1629, co spowodowało znaczne przesunięcie linii osadniczej na północ mia-

B. Dybaś, J. Tandecki przy współpr. M. Farbiszewskiego, Warszawa 1990 - XXXIII, 260, [2] s. - (Źródła i Materiały do Dziejów Sztuki Polskiej, t. 23; J. Tandecki, Statut toruńskiego bractwa sterników z 1613 roku, Rocz. Tor. 1983, t. 16, s. 257-279; tenże, Statuty toruńskiego cechu krawców polskich z połowy XVIII w., Rocz. Tor. 1990, t. 19 s. 255-271; tenże, XVI-wieczne statuty toruńskiego cechu garncarzy i zdunów, Rocz. Tor. 1986, t. 17, s. 267-279.

${ }^{10}$ Do najbardziej znanych należy ordynacja burmistrza toruńskiego Henryka Strobanda z 1596 r. dotycząca zachowania czystości w mieście, wywożenia śmieci i odpadków oraz budowy ustępów na posesjach: APT, AmT, Kat. II, I-95.

${ }^{11}$ GStAPK, XIV HA, OF sygn. 322A, Nr 3, s. 177-189. Wilkierz jest tożsamy $\mathrm{z}$ wydanym drukiem przez A. Semraua.

${ }^{12}$ Zob. Z. Zyglewski, Artykuly Mokrzańskie w roku 1527 na tle rozwoju gospodarczego i ustrojowego Mokrego - przedmieścia Torunia, Zeszyty Naukowe Wyższej Szkoły Pedagogicznej w Bydgoszczy. Studia Historyczne, z. 3, Bydgoszcz 1993, s. 15. 
sta i zmieniło zasięg zabudowy przedmiejskiej. Stąd pierwszy artykuł wilkierza określa dokładnie zasięg i granice każdego z czterech kwartałów: Rybackiego, św. Jerzego, św. Wawrzyńca i św. Katarzyny. Do każdego kwartału Rada Miejska wyznaczała zarządcę i dwóch kwatermistrzów, których zadaniem było administrowanie przedmieściami w zakresie ochrony przeciwpożarowej, kontroli tzw. ludności luźnej, handlu, gospodarki, czystości i porządku na ulicach. Problem czystości na przedmieściach został zawarty $\mathrm{w}$ osobnym artykule dotyczącym spraw budowlanych i ulic, a przepisy te niewątpliwie ujęto również pod wpływem starszych ordynacji mających na celu poprawę warunków higienicznych w mieście.

Pod względem konstrukcji tekstu wilkierz przedmiejski z 1637 r. przypomina pozostałe $\mathrm{z}$ tego okresu artykuły wydawane przez Radę miasta. Dokument rozpoczyna wyróżniony inicjałem wstęp zawierający informacje o wystawcy, dacie publikacji i treści. Całość wilkierza podzielona jest na 11 artykułów. Brakuje w nim jednak formuły kończącej, charakterystycznej dla tego typu aktów prawnych, w których mogła się znaleźć nota o sankcjach grożących za nieprzestrzeganie uchwały miejskiej.

Dokument jest czystopisem wpisanym do sztucznie utworzonej w XIX w. księgi, oprawionej w półskórek, zatytułowanej „Miscellanea Thorunensia", zawierającej różne rozporządzenia i ordynacje Rady miasta z lat 1569-1682, między innymi wilkierz miejski z 1634 r. Przy opracowaniu edycji wilkierza posiłkowano się instrukcją wydawniczą K. Lepszego dla źródeł historycznych od XVI do połowy XIX w. ${ }^{13}$

\footnotetext{
${ }^{13}$ Instrukcja wydawnicza dla źródel historycznych od XVI do połowy XIX wieku, pod red. K. Lepszego, Wrocław 1953.
} 


\title{
WILKIERZ DLA PRZEDMIEŚĆ MIASTA TORUNIA WYDANY PRZEZ RADĘ MIEJSKĄ W ROKU $1637^{14}$
}

Archiwum Państwowe w Toruniu, Księgi i akta, Kat. II, dz. I, sygn 3a, k. 150170. Wilkierz wchodzacy w sktad księgi zawierajacej zarzadzenia $i$ wilkierze Rady Miasta Torunia z lat 1569-1682, zatytułowanej Miscellanea Thorunensia. Źródto $w$ dobrym stanie, pismo czytelne, kancelaryjne, dawna foliacja atramentem. Na każdej stronie (prócz pierwszej) podkreślony nagłówek „Ordinantz der Vorstadt".

\section{ORDNUNG}

\author{
WELCHER SICH DER VORSTÄDTISCHEN QUARTIER \\ VERORDNET IN VERWALTUNG IHRES ANBEFOHLENEN \\ AMPTS WIE AUCH BÜRGER UND EINWOHNER \\ DER VORSTATD GEMASS VERHALTEN SOLLEN \\ VON EINEN EHRBAREN RADT BESCHLOSSEN \\ UND ANNO 1637 DEN 16 APRILIS PUBLICIRET
}

\section{VON QUARTIEREN DER VORSTADT}

$\mathrm{Zu}$ Stiftung und Erhaltung guter Ordnung in Vorstadt dieser Stadt gab Ehrbaren Ehrsamen Rath geschlossen, dass die Vorstädte hinführe in Vier Teile ${ }^{\mathrm{a}}$ sollen geteilet und mit Quartiermeistern versehen werden.

Von der Brücke zu dem Altthornischen ${ }^{\mathrm{b}}$ Thor und folgendes bis an die nessersse Ziegelscheune// [k.151] und so fortan, bis an der Stadt Grenze, soll heißen: Das Fischer Quartier.

Darnach von dem Altthornischen bis an das Kulmische Thor, und weiter, die Kulmische Land Straße, der Vorstädter Rossgarten ${ }^{c}$, die Vorwerke biss an die Stadtgrenze hiermit eingeschlossen, soll heißen: Sankt Georgen Quartier.

\footnotetext{
${ }^{14}$ APT, AmT, Kat. II, I-3a, k. 150-170.

${ }^{\text {a }}$ Na marginesie: Einteilung der Vorstadt in 44 Quartire.

${ }^{\mathrm{b}}$ Na marginesie: 1 . Fischer Quartier.

${ }^{\mathrm{c}}$ Na marginesie: 2. St. Georgen Quartier.
} 
Ferner von Kulmischen bis an das Gerechte Thor, und furder zur Rechten Hand, durch das Gässlein, die neue Mühle mit eingeschlossen auch ferner über die Mühlbrücke, durch das// [k. 151v] Gässlein, neben dem Acker so der Klünche Vorwerk oder Münchenberg genannt wird, bis an das Pestilenz Haus, soll heißen: Sankt Lorentz Quartier.

Redlichen von Gerechten Thor hinumb, durch das Gässlein zur ${ }^{\mathrm{d}}$ rechten Hand, neben dem Mühlteich, Trepusch, und alte Vorwerk mit eingeschlossen bis an der Stadtgrenzen, neben ${ }^{\mathrm{e}}$ dem Klösterchen, und also die Weissel herunter, bos an die lange Brücken, wird genannt das Sankt Katharin Quartier.

Des sollen zu jeden Quartier nebenst einer Person aus Mittel Erbaren Ehrsamen Rahts, als Directore// [k.152] $\operatorname{vier}^{\mathrm{f}}{ }^{\text {Quartirmeister, zwei }}$ aus der Stadt und zwei aus den Vorstadten deputiret sein und sollen ab angedeutete verordnete Quartirmeister, so vor jetzt und Künftig zu diesen Quartier Amt von Ehrbaren Ehrsamen Rath jährlichen, bald nach der Kühr erneuert und gekohren werden, auf diese Ernnten verzeichnete Artikel, so zu Bestellung gutter Ordnung und Disziplin in Vorstädten Dienlich guter auf Achtung haben.

\section{VON QUARTIERMEISTERN}

Die Quartiermeister sollen alle Quartal ordinarid, in allen// [k. 152v] vier Quartiren zugleich, sonsten aber so off die es von nobchen erachten werden, die Besichtigung ${ }^{\mathrm{g}}$ der Häuser ausstellen und die Lindeohner aller Vorstädte ernstlichen warnen, dass Sie zwischen der Zeit, welche Ihnen angesetzt wird, alles so wegen Ehrsamen Ehrbaren Raths Ihnen Besohlen, gehorsamlich ins werde setzen wollen, wo aber hiernen, Binnen ausgesetzter Zeit dem Quartiermeistern keine folge und gehorsam geleistet wurde, sollen die ungehorsamen dem Herr Directori desselben und von Ihne zur Straffe gezogen werden.//

\footnotetext{
${ }^{\mathrm{d}}$ Na marginesie: 3. St. Lorentz Quartier.

${ }^{\mathrm{e}}$ Na marginesie: 4. St. Kartharin Quartir.

${ }^{\mathrm{f}}$ Na marginesie: Wahl der Quartiermeister.

${ }^{\mathrm{g}}$ Na marginesie: Revision der Häser in der Vorstadt alle Quartal anzustellen.
} 
[k.153] Sie verordneten der Quartier sämtlich sollen alle Quartal zusammen kommen, und $v^{\text {h }}{ }^{\text {h }}$ guter Ordnung der Vorstädte Unterregung pflegen, und auf Abschaffunge allerlei wieder diese Artikel eingerissene Missbräuche und vordnungen mit sämtlichen zu Rathe bedacht sein, wo auch etwas Lauchtiges vorfallet solen sie das selbige denen aus mittel Ehrsamen Ehrbaren Raths verordnete offen Directoribus damit es Löblichen Rath vorgetragen, und dessen Zeile und Meinung hierüber// [k. 153v] nachmals ihnen umgebracht werde, anzusagen schuldig sein Beinebenst diesem sollen auch die Einwohner in jeden Quartier von desselben Quartier verordneten, durch einen Wachter ${ }^{i}$ beschickt werden, so off solches von Nöten, allda von desselben Quartiers verordneten diese ganze Vorstädter Ordnung in bei dem Sprachen, soll verlesen werden.

Wo auch jemands eines wieder diese Punkten Verbrechens und ${ }^{j}$ Excess, nach Vorgehen der ordentlicher Ladung durch den Wächter, und andere überwiesen wurde soll zu jeder Zeit unerhörten// [k.154] der allgemeinen zusammen Kunft der sahen Gelegenheit nach, vermöge dieser Artikel von den Herr Directoribus gestraft worden.

Wo jemands aus der Vorstadt sich mit Verachtung, aller unziemlichen vertan oder Werken Hegen den verordneten Quartiermeistern ${ }^{k}$ warm Sie etwas befehlen oder besichtigen werden, erzeigen werde, denselben sollen die Quartiermeister ungesäumt dem Herr Directori selbten Quartiers anmelden damit er von Ihme nach Gelegenheit des Verbrechens gestrafft werden. Im fall aber// [k. 154v] andere Bürger so in der Stadt Wohnhof, die verordneten oder ihr Ampt schimpflich und verächtlichen halten werden, wird Ehrsam Ehrbar Rath dieselben auff bildliche anklage der verordneten, anderen zum Epenges ungestrafet nicht bleiben lassen. So off die Quartiermeister dem Wachten etwas befehlen ${ }^{1}$, soll er ungesäumte dasselbe ins Werk stellen wo Er es

\footnotetext{
${ }^{\mathrm{h}}$ Na marginesie: Der Quartirmeister zusammen Kunft wann und vorzu sie anzustellen.

${ }^{\mathrm{i}}$ Na marginesie: Ordinantz der Vorstadt dem Vorstädtern vorzulassen.

${ }^{\mathrm{j}}$ Na marginesie: Übertreter der Ordinantz der Vorstadt zubestraffen.

${ }^{\mathrm{k}}$ Na marginesie: Ungehorsamt dem Quartiermeister wie sie zur Straffe zu ziehen.

${ }^{1}$ Na marginesie: Vom gehorsam der Wächtern.
} 
aber zu Thun unterließe, soll er von den Herren Directoribus zu Gefängnis verteilet werden.//

[k.155] Wiewohl Ehrsam Ehrbar Rath zuverlässiger Hoffnung von einem jeden dieses Quartieramts Verwaltern ist, es werde jeder noch er erheischung seines Gewissens, und vorgeschrieben ${ }^{\natural}$ Ordnung, am Fleiß gebührlicher execution dieser Artikel vor seine Person richtes erwidern lassen, dennoch auf den fall so Ermans von den verordneten Quartier ältesten, uber der hoffen Ehrsam Ehrbar Raths, vor jetzt und Künftiges Zeit seines anbefohlenen Amts nicht// [k. 155v] gebührlich abwarten werde angemerkt Er durch seine Fahrlässigkeit aller eingerissenen Verordnung und derselben Straffe sich Teilhaftig machet: Als will Ehrsam Ehrbar Rath Ihme die Straffe hierin Kegen einen solchen vorbehalten haben.

\section{VON EINWOHNERN DER VORSTADT}

Die Vorstadt kann bewohnet werden, nebenst den Bürgern, die sich allda nieder gelassen, von freien Leuten die zur Tauglichen Arbeit der Stadt und der Bürgerschaft dienen. Befangen// [k.156] die Kammerleute Männlichen und Weiblichen Geschlechts, weder dienen, nach bei der Stadt $^{\mathrm{m}}$ mit der Handarbeit sich ehrlichen nähren, sondern dem Spielen, Müßiggang, Purerei, und anderer Üppigkeit nachgehen, sollen nach fleißiger in Torsichung, dem Herr Directoribus oder auch dem Bürgermeisterlichen Amte nahm kündig gemacht, und vermittelst Ehrsamen, Ehrbaren Rath Erkenntnis nebenst dem Wirsche softeren und Reben, wir auch solch loses Besiedlein wissentlich heget und beherberget, mit Verteilung zur Karre an// [k. 156v] dem Wolle Verweisung der Stadt nach Gelegenheit der Sachen gestraft werden. Und soll furnemblich der Vorstädtischer Wächter auf solche beute zu jeder Zeit gute achtung geben, und wir oben gemeldet ungesäumt dem Herr Directoribus anmelden. Das ferne auch ein Melzer oder Bräuer-Knecht, so zwar Stark und zum Werk Tüchtig, jedoch des Handwerks sich leuchtfertig entschlagen, und anderer Nahrung mit Massen und Höke-

\footnotetext{
${ }^{1}$ Na marginesie: Straffe wieder die Nachwahrung Quartiermeistere.

${ }^{\mathrm{m}}$ Na marginesie: Müssiggangere und Kammer Leute in der Vorstadt.
} 
rei sich brauchen wollte in der Vorstadt befunden// [k.157] wurde, soll demselben solches nicht eher frei stehen, besseres von Ehrsamen Ehrbaren Rath erlanget. Der da wieder zu Thun sich unter Stunde, soll von dem Wachter derm Quartiermeister und folgendes von Ihnen dem Bürgermeisterlichen Amten angemeldet. Und durch dessen Erkanntnis gestrafte werden. Junglichen soll der Vorstädtische Wächtes auf die Fischern und Weinhasen in der Vorstadt hiesigen Burgere zum Vorfange sich aufhalten, gutte Achtung geben und selbte den verordneten Quartiermeister// [k. 157v] anmelden, damit sie dem Burgermeisters Ampte nahmkundig gemacht, und von hinnen abgeschaft mogen werden.

Es soll auch niemands Dienstmagde ${ }^{\mathrm{n}}$, so zu dienste sich haben bestellen lassen, zu gewohnlicher Jahrzeit, da die Dienste, bei ${ }^{\circ}$ der Herrschaften pflegen abgerechnet zu werden wie auch zu andere Zeiten in wehrenden Dienst besonders unter den Predigten aufzuhalten sich unterstehen sondern vielmehr die selben Vermachen, dass sie in ihr Dienste entretten wollen: wenniger aber, da Sie in// [k. 158] Diensten sehen, ihre Kasten, noch andere einige Ihne zugehorige Sachen zur Verwachrung auf und annehmen: Im wirdrigen fall, sollen beide Gast und Wirth als die zur untrew und diesstal unsach geben und gewienen, mit Gefangniss, Verweisung der Stadt nach gelegenheit des Verbrechnes unablasslich gestraffet werden.

Es sollen die Vorstadter Ihnen hochsten ${ }^{\mathrm{p}}$ Fleißes angelegen sein lassen, damit Ihre Kinder in aller Bottes furht und Erbarkedt erzogen mogen werden, in sonderheit// [k. 158v] aber die Tochtere vom Mussigang abhalten und wann sie $12 \mathrm{Jahr}$ verrichet, dieselben den Burgern in den Dienst geben.

Es soll auch keiner so in der Vorstadt wohnet, er wohne in seinen eigenen, oder auch gemeinteten Hause, sich ohne der Verordneten desselben Quartiers Vorwissen und zulass, weder sassen, nach einen Kammermann oder Kammerweib, oder Magd, oder Gessler zu sich umzunehmen unterstehen, bei Straffe zwei Mark, welchen Hauswirts

\footnotetext{
${ }^{\mathrm{n}}$ Na marginesie: Conf. Stadt Thorn Wilkur Art. 6 cap. 16 pag. 211.

${ }^{\circ}$ Na marginesie: Dienst Mägde bei sich zu Jahr verbote.

${ }^{\mathrm{p}}$ Na marginesie: Vorstädter Kinder zucht.
} 
dannsein negster Nachbar in solchen fall den Verordneten Quartier// [k. 159] - meister anzuzeigen schuldig, oder der Straffe 10 Gr. unterworffen sein soll desgleichen soll auf der Fischerei fleissige Achtung gegeben $^{\mathrm{r}}$ werden, dass auserhalb der Fischer, Steuerleute und anderer, derer sich wie Schippere zu ihrem Kahnen gebrauchen, keiner daselbst sich hausslichen einderlasse oder Wohne und da irgends einer oder der andere diesem zu wieder heinlich allder einschleichen solte, soll derselbe zu gebuhrlicher Straffe von den Herr Directoribus gezogen und in der Fischerei dennach nicht gelitten werden.//

[k. 159v] Es soll in der Vorstadt kein Erbes sei Haus, Scheunen, Garten, Acker ${ }^{\mathrm{s}}$ und dergleichen Verhauft noch Gerichtlich jemanns verchrieben werden, es sei dann einem Burger: Da aber einer so kein Burger were, ein Erbe an sich Brugen? wolte, derselbe soll bei E[hraber] E[hrsamen] Rath umb Verwilligung und consens des Theils anhalten, bei gelegenheit und zustand derselben Person woll kommen stehen soll.

\section{VON FEIER ORDNUNG}

Sollen die Quartiermeister, jedere in ihren Quartier in allen Gasten, von Hause zu Hause umbgehen, zu besichtigen, wo Bose// [k. 160] Schorsteine sein, und denselbigen, so Rauch halten, gebieten, die Schorstein bestermassen zu bessere, oder auch nach der gelegenheit, wo sie zur besserung nicht Tuchtig, einzureissen und die Wohnung mit einen Wohl Verwarten Schorstein zu versehen: wurder jemands solch der Quartiermeister Gebott ungesammet in Vier Wohnen nicht ins Werck stellen, soll zur andere der Quartiermeister besuchtigung, demselben von E[hrsamen] Erbaren Raths wegen auferleget werden, kein Fewer zu machen, so lande biss// [k. 160v] der Bose Schorstein wieder und gebessert, oder von neuen aufgerechtet werde bei Straffe 10 Mark, oder sehen Tage Befangniss, so oft darwieder gehandelt wird.

Imgleichen ist einem jeden Einwohner die Schorstein auf zu fegen, Lehren und wennigen, auf Zuerlegen, von E[hrsamen] Eerbaren Raths

${ }^{\mathrm{r}}$ Na marginesie: Auf der Fischerei sollen nur Fischer und Steuerleute wohnen.

${ }^{\mathrm{s}}$ Na marginesie: Von Veralienirung der Gründ in der Vorstadt. 
wegen bei Straffe 20 Gr. Buste// [k. 161] Ein jeder Wirth soll fur seiner Hausthure im Sommer, ein dass oder Butte woll mit Wasser stehen haben, bei 2 Gr. Buste.

Niemand soll mit Feuer, angezu[...]deten Kuhne und blossen Lichte, weder auf Gassen, noch in Hausern, Stallungen und Scheunen umbgehen sondern in der Laterne das Licht umbtragen bei Straffe $10 \mathrm{gr}$.

Wo jemand bei seinem Nachbaren Feuer holen wolte, soll vermoge alter guter Gewohnheit in einem Topf mit einer Sturzen zugedenkt, das Feuer holen, und nicht mit Stroh Spanen, oder Kuhe ver dawieder// [k. 161v] Thate dem soll man von sund an, so wohl wen Wirth so solches dem seinen nicht Verbietet, als das Gesiede, wie auch dem so dergestalt Feuer aus seinen Wohnhause auszutragen nachgiebt, mit Zehn Gr. Straffe oder Gefengniss belegen.

Es soll sich auch Niemand in der Vorstadt zu schusten untestehen, die Leute aber in den Hausern auf ihr Besinde fleistig Achtung geben, damit nicht bei des ihnen, wir auch den Nachbare zu schaden, ihr Gesunde durch ihre Fahrlessigkeit mit dem Feuer ein Vergluck// [k. 162] anrichten, bei Straffe E[hrsamen] Erb[aren] Raths nach gelegenheit der Sachen.

Es sollen auch in einem jeden Quartier etzliche Feuer Leitern, Feuer hacken, feuer Epmer und schwebende Wasser und Wutten auf Schliefen, oder die gewohnlichen Wasser gewasse in mittelmastiger Groste, an einem gewisten offentlichen Orte, nach Nothift des Quartiers durch die Quartiermeister richtig und fertig gehalten werden, auf unkosten jedes Quartiers, dazuauch das Straffgeld zu gebrauchen.

Dess sollen auch keine Hauser, Scheunen, oder andere// [k. 162v] Gebande in der Vorstadt weder Jetzt nach Kunftig mit Stroh oder Schindele, sondern allein mit Dachsteinen gedenket werden, bei E[hrsamen] Erbaren Raths Straffe.

Sie Leimerne Schorsteine, dodurch viel Weheil den Nachbaren zu erwachsen pfleget, sollen Numehr ganz abgeschafft und Ziegele aufgeruchtet werden, darzu fur anderen gebaude aus der Ziegelscheunen Ziegel umb Bezahlung sollen gelasst werden. 
Welcher Vorstadter und Mockerer zum leshen der Bremmd heiden, is baldes Ehme// [k. 163] angesaget, und zu leschen gebothen wird sich hier zu nicht findet, soll drei Marck Geldes zur Buste geben.

Wer selbst aus Unvermogenheit, oder Alter dahim nicht kommen kann, soll ungesaumet einen andere in seine stelle zu schicken schuldig sein bei obersezter Straffe, welche die verordneten Quartiermeister unverzuglich exequiren sollen.

\section{WACHORDNUNG}

Damit aber insonders bei nachtlicher weile, alle Anordnungendeste bester mogen abgeschaft werden, sollen vier Personen zur Wache angeordnet werden// [k. 163v], welche alle Abend und Nachte zweimahl in allen Gassen der Vorstadt umbgehen, gutte Achtung auf alle Dinge Furhemlichen auf Licht und Feuer haben mogen. Sollen hieruben bei diesem umbgeng, auch die selbten, so lande in die Nacht sitzen, mit Sauffen, Spielen, Tanzen, tauhzen, schreien und anderer Leichtfertikeit sich upfig erzeigen, vermachen, Sie des Langen sitzens sich enthalten und und zu Siche sich mit umbescheidene worden oder auch mit Thatlicher Hand anlegung an ihnen sich vergreiffen, oder// [k. 164] auch derselbsten Vermahnung nach, von dem langen sitzen sich nicht enthalten wurde soll der Wachter solches dem Nacht Schultzen einbringen, welcher nachmals entweder mit aufhebung derselbsten Leute, oder auch in andere weise der Sachen gebuhr thun und wie sie sich ferner verhalten sollen, ihnen wird zu befehlen wissen.

So auch der Machter entweder aus Kundschaft oder augenscheinlicher selbst abmerkung, was dieser abaugetzten Ordnung zuwieder, an Jemands verspuren, soll er des Quartiers, darumter der Verbrecher// [k. $164 \mathrm{v}$ ] gelegen, verordneten solches anzeigen, und ferners bescheid sich bei Ihnen erholen.

\section{BAU-GASSEN UND HOLTZ ORDNUNG}

Es soll sich auch Niemands unterfangen seine Wohnung am die bei der Stadt Rechten zum Vorfang außerhalb seines eigenen Grundes heraus zu bauen, bei Strafe $10 \mathrm{Mr}$. Und Wandel des Gebäudes. 
Die Vorstädter wie auch Burger sollen ihre Schichten Holtz als setzen, damit wie Gassen nicht mögen verleget werden. Wer solches täte nach geschehener ersten Warnungen, den sollen die Quartiermeister dem Herr Directori// [k. 165] desselben Quartiers anmelden, welcher Ihn nach Gelegenheit der Sachen wird zu straffen wissen.

Es sollen auch die Gassen mit Rahnen und Holtz nicht verleget und der Zutritt zu dem Brunnen mit Ansetzung des Holzes, nicht Verhindert werden, bei Verlust des Holzes.

Siefuro soll auch in der ganzen Vorstadt und allen derselben Gassen, außerhalb ihrer Garten und Wohnungen, niemands Holzschichten setzen, nicht mit Holz verlegen, oder mit ein Setzung der Pfalen, die Straße.// [k. 165v] Ziederen bei einer Mark unablöslicher Busse.

Weil auch biss anhero in der Vorstadt das Holz der Burgerschafft entfremdet, in Schichte gesetzte, und wieder umb Verkaufet ist worden, als soll hinführe keinem Vorstädter, so nicht Bürgerrecht hat, das kaufen und verkaufen des Holzes bei dieser Stadt, wie auch Schichten zum verkauft zu sitzen verstattet werden, dann nur so viel Holzes, als Ihnen zu Ihrer Häuslichen Notieren von Nöten wer dann wieder Handen wurde, soll von den Quartiermeistern den Herr// [k. 166] Directoribus angemeldet, und von Ihnen gestraffet werden.

Die Gassen sollen rein gehalten werden, und ein jeder soll schuldig sein vor seiner Thur und Thoren, den Mist wegzufuhren, bei Straffe 10 Gr[oschen].

Wo Steinbrücken in den Gassen sein, dieselben sollen mit dem Mist nicht beleget, wie auch andere Gassen, so keine Steinbrücken haben, mit übrig großen häufen Mistes nicht bei schüttet und verfüllet werden, bei Straffe jedes mahl 10 Groschen.

Wo jemand betroffen oder dessen überzeuget wurden, dass er// [k. 166v] Mist oder Briss, oder sonst hinderliche Unsauberkeit in die Bache oder Brunnen geworfen, soll drei Mark Geldes zur Busse geben, so off da wieder gebrachen wird.

Da auch jemands beschlagen würde dass er Rosse zur Tränke in dem Wallgraben reitet, selbiger mit Gefängnisse so off er da wieder verbricht, gestrafft werden. 
So jemand beschlagen, oder dessen genugsam überwiesen wurde, dass er den Nachbaren die Zumer gebrachen, soll öffentlich andere zu dem ende aufgerichteten Seule mit dem Halseisen gestraffte werden.//

[k. 167] Belangende das Gerurmicht die Rauchen auf den Baumen in den Garten soll Nachbar bei Nachbar Jahr Jährlich zu rauchen Verpflichte sein, bei der Busse drei Mark.

\section{VIES ORDNUND}

Es soll kein Burger in der Vorstadt einen besonderen Hirten fur sein Vieh halten, nach dasselbe insonderheit zur wieder Weibe oder Hutten lassen bei Straffe fünf Groschen von jeder Haupt Vieh, so off er von wieder zu tun beschlagen wird, zu Verbüßen. Den Vorstädtern aber, so nicht Burger sind, und// [k. 167v] sonsten mit der Täglichen Arbeit ihr Brod werben kommen, als Hornträgern, Messern, Tagelöhnere und anderen ingemein soll weder Viehe zu Nutz und Massung, noch Rosse zu halten bei Verlust des Viehes frei stehen; es habe es dann jemand nach eingebrachten rechtmassige ersachen von E[hrsamen] E[hrbaren] Rath oder dem Herr Directore selben Quartiers, darinnen Er wohnet wann es vorher E[hrsamen] E[hrbaren] Rath der selbe referirte, und Ihnen solches von E[hrsamen] E[hrbaren] Rath mitgegeben worden, erhalten, als dann und nicht eher der Vieh Hirt, der Vorstädter so nicht Burger sind// [k. 168] habendes Viehe anzunehmen befuget sein soll. Den fuhrerurten aber soll Rosse, wie auch alten verlebeten Leuten, Viehe zu halten, wann es E[hrsamen] E[hrbaren] Rath Ihnen nachgegeben, unbewehrte sein.

Es soll auch keinen Meltzer oder Brauerknecht laut Ihrer Rolle, Viehe zu halten frei stehen, ausgenommen ein Schwein oder Bork zu seiner Notdurft in seinem Hause bei Verlust des Viehes so er darüber betroffen wurde; welches auch von denjenigen so es nicht zu sonst somme$\mathrm{re} / /[\mathrm{k} .168 \mathrm{v}]$ an fremden Örter verborgen halten und aufziehen, verstanden werden soll. 


\section{VOM BIER UND BRANDT WEIN SCHANK}

Niemand soll in der Vorstadt Bier schenken, er habe dann das Burgerrecht und dem Bier schank von E[hrsamen] E[hrbaren] Rath erhalten, bei der Erb[ahren] Melde erester Straffe und Execution. Es soll auch kein Vorstadter, er sei Burger oder nicht, dem Brandwein zu verschenken sich unter stehen, er habe es dann von E[hrabren] E[hrsamen] Rath vorhin erhalten. Der dar wieder thutt soll von der Erb[ahren] Watte gestraffte werden.//

\section{[k. 169] IX. VOM HABERKAUF}

Sein Vorstädter ein gemein, und sonderlichen ${ }^{t}$ denjenigen, so Gasthäuser aus zulässt E[hrsamen] E[hrbaren] Rath halten, soll der Haberkauf in den Vorstadten ganz verboten sein, da sie aber entweder vor sich oder ihre Gaste dessen benötiget sollen sie denselben in der Stadt, wie vor diesem brauchlich, bei den Bürgere und Kaufleuten einkaufen auf eine Zeitlang versorgen, wird jemand vor wieder handeln soll deselbe vor die Ehrbare Rath geladen, und nach der Kandniss, // [k. 169v] so off er verbrechen wird gestraffet werden.

\section{VOM VORFANGLICHEN EINKAUF DER VICTUALIEN}

Weil augenscheinlich verspüret wird, dass die Einwohnern der Vorstadt, dem Bürgere zum merklichen verfang, in der Vorstadt allerhand Victualie einkaufen, als sollen sie sich dessen ins künftige enthalten, bei confiscirung dessen, was einer oder der andere einkaufe wurde, und bei E[hrsamen] E[hrbaren] Rath erster Braffe.//

\section{[k. 170] XI. VON GASTHAUSEM}

Es soll sich niemand unterstehen in der Vorstadt ohne E[hrsamen] $\mathrm{E}$ [hrbaren] Raths zulässt, Gasthäuser an zu stellen, und diejenigen, so da aufgerichtet sollen abgeschafft werden. Wer dar wieder verbrechen wird, den sollen die Quartiermester dem Herr Diectori denselben Quartiers anmelden, welcher Ihn nach Gelegenheit der Sachen, wird zu straffen wissen.//

\footnotetext{
${ }^{\mathrm{t}}$ Na marginesie: Reformat Artikeln, Artic. 25 pag. 22.
} 


\title{
WILKIERZ DLA PRZEDMIEŚĆ MIASTA TORUNIA WYDANY PRZEZ RADĘ MIEJSKĄ W ROKU $1637^{15}$
}

\author{
ZARZĄDZENIE, \\ KTÓRE NAKAZUJE KWARTAŁOM PRZEDMIEŚĆ, \\ JAK I OBYWATELOM I MIESZKAŃCOM PRZEDMIEŚĆ \\ ODPOWIEDNIO ZACHOWYWAĆ SIE W ADMINISTROWANIU \\ POWIERZONYM IM URZĘDEM, UCHWALONE \\ PRZEZ SZACOWNĄ RADE \\ I PUBLIKOWANE 16 KWIETNIA 1637 ROKU
}

\section{O KWARTAŁACH PRZEDMIEŚĆ}

Dla utrzymania i zachowania dobrego porządku na przedmieściach tego miasta daje Szacowna Rada postanowienie, że przedmieścia te winny być podzielone na kwartały z pilnującymi je kwatermistrzami.

[Kwartał] od mostu do Bramy Starotoruńskiej i następnie do najdalszej cegielni, odtąd aż do granicy miasta, powinien nazywać się Kwartałem Rybackim.

Potem od Bramy Starotoruńskiej do Bramy Chełmińskiej i później drogą chełmińską do rozgartu przedmiejskiego, folwarku aż do granic miasta, zamykając się tam, powinien nazywać się Kwartałem św. Jerzego.

Następnie od Bramy Chełmińskiej do Prawych Wrót ${ }^{16}$ i dalej na prawą stronę przez gościniec do nowego młyna z otoczeniem, mostem młyńskim przez gościniec obok pola i folwarku „München” lub zwanego też „Münchenberg” do przytułku ${ }^{17}$, powinien się nazywać Kwartałem św. Wawrzyńca.

Na prawą stronę od Prawych Wrót, w górę gościńcem na prawo, obok Stawu Młyńskiego i starego folwarku zamykając do granicy

\footnotetext{
${ }^{15}$ APT, AmT, Kat. II, I-3a, k. 150-170. Tłumaczenie: Mateusz Superczyński, konsultacja językowa: dr Liliana Lewandowska.

${ }^{16}$ Nieistniejąca brama miejska Nowego Miasta Torunia, stojąca u zbiegu dzisiejszych ulic Prostej i Dominikańskiej.

${ }^{17}$ Dawny przytułek i szpital w okolicach nieistniejącego kościoła św. Jerzego. W okresie średniowiecza leprozorium dla trędowatych.
} 
miejskiej, obok Kaszczorka, a także wzdłuż Wisły do długiego mostu, powinien się nazywać Kwartałem św. Katarzyny.

Do każdego kwartału Szacowna Rada wyznacza po jednej osobie jako zarządców - czterech kwatermistrzów - dwóch z miasta i dwóch z przedmieść oraz powinna Szacowna Rada wspomnianych kwatermistrzów od teraz i w przyszłości corocznie zmieniać i wybierać po kierze, co też podaje niniejszy artykuł dla ustanowienia lepszego porządku i dyscypliny na przedmieściach ku dobremu pożytkowi.

\section{O KWATERMISTRZACH}

Kwatermistrzowie powinni zarządzać wszystkimi kwartałami, jak i we wszystkich czterech kwartałach jednocześnie dokonywać uważnie inspekcji domostw oraz mieszkańców wszystkich przedmieść w czasie, który im Szacowna Rada w pełnej zgodzie wyznaczy, a w przypadku nieposłuszeństwa wobec panów zarządzających powinno się $\mathrm{w}$ konsekwencji pociągnąć do odpowiedzialności.

Przypisane im kwartały powinni wspólnie nachodzić i dla dobrego porządku na przedmieściach utrzymywać w nich nadzór, a także zwracać uwagę na zniesienie różnorodnych nadużyć i służyć wszystkim radą, wskazując na artykuły, jeśli zdarzy się coś nadzwyczajnego, winni oni przedstawić to zarządzonym przez Szacowną Radę publicznym zarządcom, a tym samym Szacownej Radzie, której stanowisko będzie im ponownie przekazane. Ponadto mieszkańcy w każdym kwartale zarządzanym przez kwatermistrza powinni trzymać straż [potrzebną] w razie konieczności, a cały porządek przedmieść winien zostać przez tych samych kwatermistrzów odczytany publicznie.

Jeśli ktoś popełni przestępstwo lub jaki eksces wobec tych punktów i wystąpi przeciw porządkowi, zostanie pozwany i przez straż przekazany; powinien w tym czasie zostać niezwłocznie ukaranym przy najbliższej sposobności, zgodnie z tymi artykułami przez pana zarządcę.

Jeśli ktoś z przedmieść traktuje z pogardą całą pracę i działa przeciw kwatermistrzom w trakcie wykonywania ich obowiązków i przeglądu, powinien zostać wskazany i tegoż kwatermistrz winien przekazać panu zarządcy, któremu przypisany jest kwartał, po czym niezwłocznie, po dokonanym występku zostanie ukarany. W przypadku 
innych obywateli zamieszkałych w mieście, którym przypisze się traktowanie haniebne i pogardliwe dla urzędu, Szacowna Rada, oskarżając ich za obrazę, nie pozostawi ich bezkarnymi. Tak też kwatermistrz rozkaże straży, że powinna ona takowego, który przerywa pracę, zatrzymać i powinien on zostać przez panów zarządców wtrącony do więzienia.

Chociaż Szacowna Rada z wiarygodnością darzy zaufaniem każdego z kwatermistrzów, to wymaga od nich więcej jeszcze sumiennego i przepisowego porządku i pilnego egzekwowania stosownych artykułów w stosunku do każdej osoby. Jednakże w przypadku, gdy w danym kwartale Szacowna Rada od teraz i w przyszłości, zauważy lub dostrzeże, że przypisane polecenia są wykonywane niestosownie, jak i cały zarząd pełniony jest w niedbalstwie, zostanie on [kwatermistrz] pociągnięty do odpowiedzialności karnej. Wówczas Szacowna Rada zastrzega sobie nałożenie na niego kary.

\section{O MIESZKAŃCACH PRZEDMIEŚĆ}

Przedmieścia mogą być zamieszkiwane, obok obywateli, także przez wszystkich wolnych ludzi zdolnych do pracy w mieście i służących obywatelom. Problemem są nie komornicy, płci męskiej jak i żeńskiej, służący w mieście pracą ręczną i uczciwie żyjący, lecz zajmujący się graniem, próżniactwem, cudzołóstwem i innymi zbytecznymi rzeczami, powinni zostać przysposobieni do pracowitości przez pana zarządcę lub też urząd burmistrzowski, a ich luźne zasiedlenie będzie karane wydaleniem $\mathrm{z}$ miasta według okoliczności sprawy. Powinny również straże przedmiejskie mieć baczenie na takich ludzi i dobrą uwagę oraz powinni o nich donosić panu zarządcy. Także w przypadku pachołków browarniczych i w słodowni, chociaż zdecydowanie wykonują sumienną pracę, to jednakże lekkomyślnie szkodzą w rzemiosłu. Jeśli znalazłby się na przedmieściach ktoś, kto zarabiałby na pożywienie cudzołóstwem, nie powinien on raczej pozostać wolno, lecz uzyskać zgodę od Szacownej Rady na to. O tym zaś, kto będzie się wymigiwał, by to czynić, straż winna zawiadomić kwatermistrza, ten zaś urząd burmistrzowski. I przez to doniesienie zostanie on ukarany. Straż przedmiejska powinna mieć baczenie na młodzież z Rybaków i Winnicy, zatrzymaną przez 
obywateli na przedmieściu, i dając ostrzeżenie powinno się zawiadomić o tym odpowiednio przypisanego kwatermistrza, aby urząd burmistrzowski pozbył się ich stamtąd.

Nikt zaś nie powinien zatrzymywać dziwek, które zatrudniły się na służbę, na zwyczajowy rok czasu, które zaniedbują służbę szczególnie u kaznodziejów [?], ale o wiele bardziej zachęcać je, by pełniły tę służbę. Jednak, kiedy pełnią służbę, ich skrzynie i inne przynależne do nich rzeczy winno się przyjąć na przechowanie. W szczególnym wypadku zarówno gość, jak i gospodarz, których podejrzewać można o niewierność i kradzież, powinni być niezwłocznie ukarani więzieniem, wydaleniem z miasta według okoliczności przewinienia.

Powinni przedmieszczanie powziąć najwyższe starania, aby ich dzieci mogły zostać wychowane wszystkie w bogobojności i pracowitości, w szczególności, aby córki strzec przed próżniactwem i kiedy ukończą lat 12 oddawać je na służbę obywatelom.

Nie powinien nikt także, kto mieszka na przedmieściu, czy to we własnym, czy w wynajmowanym domostwie, poza wiedzą i zgodą zarządców tego samego kwartału przyjmować komorników, dziewki i czeladników pod groźbą kary 2 grzywien, które gospodarz w takim przypadku musi zapłacić przypisanemu kwatermistrzowi lub w zależności od winy - karę 10 groszy. Tak samo powinno się mieć baczenie na Rybakach, ale poza rybakami, sternikami i innymi, jak szyprami potrzebującymi łodzi, którzy nigdzie nie zamieszkują na stałe ani nie posiadają domostwa. A inni, którzy się zakradają i ukrywają, powinni być stosownie pociągnięci do kary przez pana zarządcę, po czym nie powinni być tolerowani na Rybakach.

Nie powinna na przedmieściu żadna ziemia, dom, szopa, ogród czy pole dziedziczone, być sprzedawana inaczej, jak tylko sądownie, każdorazowo zapisując, jeśli czyni to obywatel. Jeśli zaś nie jest to obywatel, a chciałby przekazać ziemię, powinien on przed Szacowną Radą starać się o aprobatę i pozwolenie, stawiając się przed nią z tej okazji osobiście. 


\section{O PRZEPISACH OGNIOWYCH}

Powinien kwatermistrz, każdy w swoim kwartale, we wszystkich gospodach, od domu do domu nachodzić w celu dokonania oględzin, gdzie są złe kominy i które zatrzymują dym, nakazując je poprawić na lepsze lub przy sposobności, gdzie nie są poprawiane zbyt sumiennie, przystosować komin w domostwie do sprawności. Jeśli ktoś nie wykona nakazu kwatermistrza w przeciągu 4 tygodni, winien być przy ponownej wizycie kwatermistrza nałożony na niego z uwagi na Szacowną Radę [zakaz] palenia ognia tak długo, dopóki zły komin nie zostanie ponownie poprawiony lub od nowa wykonany, pod karą 10 grzywien lub 6 dni aresztu.

Podobnie, jeśli jakiś mieszkaniec nie czyści i nie opróżnia komina, Szacowna Rada nałoży z tego powodu na niego karę 20 groszy. Każdy gospodarz powinien dla swojego domostwa mieć latem stojącą kadź $\mathrm{z}$ wodą pod karą 2 groszy.

Nikt nie powinien poruszać się po ulicach z otwartym ogniem, jak i w domu, stodole i szopie, lecz tylko z zapaloną latarnią, pod karą 10 groszy.

Jeśli ktoś chce w swoim sąsiedztwie trzymać ogień, powinien dla lepszego nawyku nosić odkryty garniec wody i nie trzymać ognia przy ciętej słomie lub szmatach. Kto czyniłby przeciw temu [nakazowi], zarówno gospodarz, który nie zabrania tego swoim pachołkom, jak i służba, czy każdy, który w ten sposób wynosi ogień ze swojego domu, winien być obłożony karą 10 groszy lub aresztu.

Nie powinien także nikt na przedmieściu poddawać tego w zaniedbanie, a ludzie w domach powinni mieć baczenie na swoje zdrowie, aby nie wyrządzić także szkód w swoim sąsiedztwie i na swoim zdrowiu poprzez nieostrożność i nieszczęście z ogniem, pod karą Szacownej Rady, jaką nałoży w tej sprawie.

Powinno być także w każdym kwartale kilka latarń, siekier i wiader $\mathrm{z}$ wodą przygotowanych w pewnym publicznym miejscu i gotowych $\mathrm{w}$ razie wypadku w kwartale, trzymane przez kwatermistrza na koszt każdego kwartału, w razie potrzeby także z kar pieniężnych. 
Nie powinien także żaden dom, szopa ani inny budynek na przedmieściu od teraz i na przyszłość być kryty słomą lub trzciną, lecz tylko samą dachówką pod karą Szacownej Rady.

Zapchane kominy wyrzucające wiele dymu w sąsiedztwie powinno się utrzymywać w czystości, a także obudować cegłą, tak jak na innych budynkach, cegła $\mathrm{z}$ cegielni powinna być pozostawiona bez opłaty.

Jeśli który przedmieszczanin lub mokrzanin będzie wypalał łąkę i prędzej tego nie zapowie, powinien dać trzy grzywny kary.

Kto $\mathrm{z}$ powodu niemocy lub wieku nie może przybyć, powinien kogoś innego wysłać z długiem pod wyższą karą, którą kwatermistrz niezwłocznie powinien wyegzekwować.

\section{ZARZĄDZENIE O STRAŻY}

Zwłaszcza dotyczące nocy, znoszące wszystkie inne zarządzenia, według którego cztery osoby powinny być mianowane na strażników, którzy każdego wieczoru i każdej nocy po dwa razy winni obejść wszystkie ulice przedmieścia, mając dobre baczenie na wszystkie rzeczy, szczególnie zaś na światło i ogień. Jeśli podczas oględzin zostaną nakryci ci, którzy w nocy długo przesiadują z pijaństwem, graniem, tańcami, wrzaskami i innymi bezmyślnymi czynami, winni być oni upomniani, by powstrzymali się od przesiadywania i zajęli się czymś skromniejszym, lub też należy stanowczo do nich podejść, a jeśli po upomnieniu nie powstrzymają się od długiego przesiadywania, strażnik winien zaprowadzić takowych do nocnej straży, która załatwi sprawę albo przez zatrzymanie takich ludzi, albo w inny sposób, i nakaże im, jak mają się zachowywać dalej.

Powinni także strażnicy lub też ktoś znany ograniczać tych, którzy naruszają porządek, jak wskazano w niniejszym zarządzeniu, poprzez wyszukiwanie przestępców i donoszenie na nich.

\section{ZARZĄDZENIE BUDOWLANIE, ULICZNE I DRZEWNE}

Nie powinien nikt także zakładać swojego domostwa pod prawem miejskim poza swoimi gruntami do zabudowy pod karą 10 grzywien i rozbiórką budynku. 
Przedmieszczanie, jak i obywatele nie powinni swoich stert drewna układać tak, aby zalegały na ulicy. Jeżeli ktoś czyni tak nadal, po pierwszym ostrzeżeniu, powinien kwatermistrz donieść o tym panu zarządcy tegoż kwartału, któremu podlega w tej sprawie i poddać karze.

Powinno się także opróżnić ulice $\mathrm{i}$ ich otoczenie $\mathrm{z}$ drewna, aby nie zalegało, i nie powinno się ograniczać dostępu do studni zalegającym drewnem pod karą jego utraty.

Nie powinien nikt także na ulicach przedmieść poza swoim ogrodem lub domostwem stawiać sterty i układać drewno ani stojących pali na ulicy pod groźbą niezwłocznej kary 1 grzywny.

Ponieważ na przedmieściu drewno ułożone w stertach wykorzystują także obywatele, jak i sprzedają je, nie powinien żaden przedmieszczanin nie mający prawa obywatelskiego kupować lub sprzedawać drewna dla miasta, jak i sprzedając stawiać sterty, tylko tyle, ile potrzebuje dla swojego domostwa, a kto może handlować, powinno być to odnotowane i przez kwatermistrza doniesione panu zarządcy pod groźbą kary.

Ulice powinny być utrzymane w czystości i każdy winien jest wywozić gnój poza swoje drzwi i bramę pod karą 10 groszy.

Ulice, które posiadają kamienne mosty, nie powinny zalegać gnojem, podobnie jak i ulice nie posiadające mostów nie mogą zalegać dużą ilością nieczystości i nie wolno na nie wyrzucać gnoju pod karą 10 groszy.

Jeżeli ktoś zostanie przyłapany i wskazany, że gnój, śmieci lub zalegające nieczystości wrzuca do Strugi ${ }^{18}$ lub do studni, powinien zapłacić 3 grosze kary z tego tytułu, ilekroć to uczyni.

Jeśli ktoś zostanie zauważony, że wjeżdżał konno do wodopoju w rowie zostanie ukarany za to przewinienie więzieniem, ilekroć to uczyni.

Jeśli ktoś przekaże, zostanie przyłapany lub udowodni się mu, że w sąsiedztwie zniszczył płot, zostanie publicznie ukarany przez przykucie kuną ${ }^{19}$ do końcówki postawionego słupa.

\footnotetext{
${ }^{18}$ Struga Toruńska, mająca swoje źródło w jeziorze Wieldządz, przepływa przez przedmieście Mokre i Staw Kaszownik do Wisły. Obecnie często nazywana Bachą (od niem. der Bach - strumień).
} 
Oskarżony o spalenie drzewa w ogrodzie powinien sąsiadowi rocznie zadośćuczynić pod karą 3 grzywien.

\section{ZARZĄDZENIE O BYDLE}

Nie powinien żaden obywatel na przedmieściu samemu trzymać bydła, jak tylko pod opieką pastuchów, specjalnie zatrudnionych kobiet lub pachołków, pod karą 5 groszy za jedną sztukę bydła, którą zmuszony będzie pokryć, ilekroć tak uczyni. Tylko przedmieszczanie, nie zaś obywatele, zarabiający dzienną pracą na swój chleb, najmując się jako tragarze zboża, miernicy, pracownicy dniówkowi i inni, nie mogą trzymać bydła ani koni dla swoich korzyści, pod karą utraty bydła; jeśli zaś trzyma je po prawidłowo złożonej prośbie do Szacownej Rady lub pana zarządcy tegoż kwartału, tam gdzie mieszka, jeśli przedtem poinformował o tym Szacowną Radę i otrzymał odpowiedź od Szacownej Rady, tylko wówczas i w żadnym innym wypadku pastuch bydła i przedmieszczanin, którzy nie są obywatelami, mają prawo trzymać bydło. Trzymanie bydła i koni przez powyższych, jak i starszych ludzi, jeśli Szacowna Rada wyraziła na to zgodę, winno być nienaruszalne.

Nie powinien żaden słodownik ani pachołek browarniany, zgodnie ze swoimi statutami, trzymać wolno bydła, $z$ wyjątkiem świń lub wieprzy na swoje potrzeby, w swoim domu, pod karą utraty bydła. Powinien zostać tak ukarany również ten, który latem będzie ukrywał [bydło] w obcych miejscowościach w celu hodowli.

\section{O SZYNKOWANIU PIWA I GORZAŁKI}

Nie powinien nikt na przedmieściu szynkować piwem, niezależnie od tego, czy otrzymał prawo obywatelskie i prawo do wyszynku od Szacownej Rady, pod karą aresztu i egzekucji. Nie powinien żaden przedmieszczanin ani żaden obywatel dawać gorzałki do szynkowania bez zgody Szacownej Rady. Czyniących tak Szacowna Rada powinna ukarać.

\footnotetext{
${ }^{19}$ Metalowa obręcz na szyi skazańca.
} 


\section{O SPRZEDAŻY W KRAMACH}

Niegodziwym mieszkańcem przedmieścia jest szczególnie ten, kto w gospodzie bez otrzymanej zgody od Szacownej Rady handluje, co jest na przedmieściu zabronione; ale na potrzeby swoich gości powinien zakupywać u obywateli i kupców w mieście; jeśli jednak ktoś tak handluje, powinien za ten występek zostać ukarany po stawieniu się przed Szacowną Radą.

\section{O KŁOPOTLIWYM HANDLOWANIU WIKTUAŁAMI}

Ponieważ wyraźnie widać, że mieszkańcy przedmieść istotnie działają na niekorzyść obywateli, handlując różnorakimi wiktuałami na przedmieściu, powinno się takich w przyszłości powstrzymać, konfiskując to, co oni lub inni będą kupować, i powinni zostać przez Radę ukarani.

\section{O GOSPODACH}

Nie powinien nikt na przedmieściu, bez zgody Szacownej Rady, zakładać gospody, a te, które już założono, winny zostać zlikwidowane. Jeśli ten występek będzie się powtarzał, powinien kwatermistrz zawiadomić o tym pana zarządcę tegoż kwartału i według okoliczności sprawy winnego ukarać.

\section{Bibliografia}

Źródła rękopiśmienne

Archiwum Państwowe w Toruniu, Akta miasta Torunia, Katalog I, dokumenty i listy, sygn. 2943; Katalog II, sygn. I-1, I-3a, I-95.

GStAPK, XX. HA, sygn. OF 83.

GStAPK, XIV HA, sygn., 322A Nr 3.

\section{Źródła drukowane}

Ciesielska K., Statut toruńskiego cechu murarzy z 1593 roku, Zapiski Historyczne, t. 27: 1962, z. 2, s. 213-228.

Das Kulmer Gerichtsbuch 1330-1430. Liber memoriarum Colmensis civitatis, bearb. von C. A. Lückerath und F. Benninghoven, Köln 1999. 
Dybaś B., Statut toruńskiego bractwa czeladzi murarskiej z 1617 r., Rocznik Toruński, t. 18: 1988, s. 193-208.

Magdański M., Statut Toruńskiego Bractwa Czeladzi Ciesielskiej z 21grudnia 1613 roku, Roczniki Historyczne, t. 13: 1937, s. 52-61.

Prawo starochetmińskie 1584 (1394), pod red. W. Maisla i Z. Zdrójkowskiego, przekł. A. Bzdęga i A. Gaca, Torun 1985.

Semrau A., Die Willkur der Stadt Kulm von etwa 1400, Mitteilungen des Coppernicus Vereins für Wissenschaft und Kunst zu Thorn, H. 37, Thorn 1927, s. $29-58$.

Statut toruńskiego rzemiosła artystycznego i budowlanego z XVI-XVIII w., wyd. B. Dybaś, J. Tandecki przy współpr. M. Farbiszewskiego; Warszawa 1990 - XXXIII, 260, [2] s.

Tandecki J., Statut toruńskiego bractwa sterników z 1613 roku, Rocznik Toruński, t. 16: 1983, s. 257-279.

Tandecki J., XVI-wieczne statuty toruńskiego cechu garncarzy i zdunów, Rocznik Toruński, t. 17: 1986, s. 267-279.

Tandecki J., Statuty toruńskiego cechu krawców polskich z połowy XVIII w., Rocznik Toruński, t. 19: 1990, s. 255-271.

Zyglewski Z., Artykuły Mokrzańskie w roku 1527 na tle rozwoju gospodarczego i ustrojowego Mokrego - przedmieścia Torunia, Zeszyty Naukowe Wyższej Szkoły Pedagogicznej w Bydgoszczy. Studia Historyczne, z. 3, Bydgoszcz 1993, s. 15.

\section{Literatura}

Maciejewski T., Wilkierze miasta Torunia, Poznań 1997.

Tandecki J., Średniowieczne księgi wielkich miast pruskich jako źródła historyczne i zabytki kultury mieszczańskiej (organizacja władz, zachowane archiwalia, działalność kancelarii), Warszawa-Torun 1990. 